\title{
Bilateral Optic Disc Edema in a Patient with Lead Poisoning
}

\author{
Paolo Pigatto $^{1,2}$, MD; Gianpaolo Guzzi ${ }^{3}$, DDS \\ ${ }^{1}$ Clinical Dermatology, IRCCS Istituto Ortopedico Galeazzi, Milano MI, Italy \\ ${ }^{2}$ Department of Biomedical, Surgical and Dental Sciences, University of Milan, Milan, Italy \\ ${ }^{3}$ Italian Association for Metals and Biocompatibility Research - AIRMEB, Milan, Italy
}

J Ophthalmic Vis Res 2021; 16 (3): 524-525

Dear Editor,

In their important contribution as a "Case Report", Abri Aghdam et al ${ }^{[1]}$ described a man with bilateral optic disc edema due to lead $(\mathrm{Pb})$ poisoning and complicated by opium addiction. ${ }^{[1]}$ This is an excellent description of papilledema induced by $\mathrm{Pb}$ overexposure,$^{[1]}$ which is a rare but serious optic nerve damage attributed to systemic $\mathrm{Pb}$ toxicity. ${ }^{[2,3]}$

However, we would like to emphasize the role of whole-blood in diagnosing the $\mathrm{Pb}$ poisoning. The patient's serum contained very high levels of $\mathrm{Pb}$, which was $164 \mu \mathrm{g} / \mathrm{dL} .{ }^{[1]}$ In humans, the normal blood $\mathrm{Pb}$ level is zero. ${ }^{[4,5]}$

We wonder whether whole-blood $\mathrm{Pb}$ concentrations were determined. In our view, the serum is not the primary and proper indicator medium as a biomarker of $\mathrm{Pb}$ exposure. In fact, serum alone (with no red blood cells) does not adequately reflect the $2 \%$ of the total body burden of the $\mathrm{Pb}$, which is found in the circulating wholeblood. ${ }^{[4,5]}$

\section{Correspondence to:}

Gianpaolo Guzzi, DDS. Italian Association for Metals and Biocompatibility Research - AIRMEB (not-for-profit organization), Via A. Banfi, 4, 20122 Milan, Italy. E-mail: gianpaolo_guzzi@fastwebnet.it

Received: 13-02-2021

Accepted: 13-04-2021

\section{Access this article online}

Website: https://knepublishing.com/index.php/JOVR DOI: 10.18502/jovr.v16i3.9450
In toxicology, the whole-blood $\mathrm{Pb}$ concentrations have been used in conjunction with urinary $\mathrm{Pb}$ levels as a primary measure of $\mathrm{Pb}$ exposure in humans. ${ }^{[6]}$

Toxicological studies suggest that exposure to $\mathrm{Pb}$ during developmental periods may lead to longterm visual deficits both in in vitro and in animal models. ${ }^{[7]}$

Toxic optic neuropathy may be the unique clinically significant alteration in patients with $\mathrm{Pb}$ poisoning. ${ }^{[2,3]}$ Fortunately, $\mathrm{Pb}$ poisoning is a rare circumstance not commonly encountered by ophthalmologists. ${ }^{[8-11]}$ Consistent with this notion, $\mathrm{Pb}$ and other toxic metals (i.e., organic mercury, thallium) are to be considered "neurotoxicants", primarily due to toxic effects on the optic nerve. ${ }^{[12-14]}$

With regard to the issue of toxic optic neuropathy, over the past two decades, we have noticed only one case in which papilledema was associated with overexposure to nickel salts. Their interesting case report ${ }^{[1]}$ reminds us that $\mathrm{Pb}$ poisoning is a topic of growing interest among ophthalmologists ${ }^{[15]}$ and conveys the fact that the eyes can be injured due to $\mathrm{Pb}$ intoxication.

This is an open access journal, and articles are distributed under the terms of the Creative Commons Attribution-NonCommercial-ShareAlike 4.0 License, which allows others to remix, tweak, and build upon the work non-commercially, as long as appropriate credit is given and the new creations are licensed under the identical terms.

How to cite this article: Pigatto P, Guzzi G. Bilateral Optic Disc Edema in a

Patient with Lead Poisoning. J Ophthalmic Vis Res 2021;16:524-525. 


\section{Financial Support and Sponsorship}

Nil.

\section{Conflicts of Interest}

There are no conflicts of interest.

\section{REFERENCES}

1. Abri Aghdam K, Zand A, Soltan Sanjari M. Bilateral optic disc edema in a patient with lead poisoning. J Ophthalmic Vis Res 2019;14:513-517.

2. Boudouresques J, Guillot P. [Papilledema, solitary manifestation of lead poisoning]. Mars Med 1957;94:693695.

3. Viaud M, Greau H, Colas J, Baron A, Lhermitte R. [Lead poisoning encephalopathy with papilledema; value of treatment with chelating agents; report of a case]. Rev Otoneuroophtalmol 1958;30:191-198.

4. Guzzi G, Spadari F, Bombeccari GP, Pigatto PD. Maxillofacial gunshot wounds and diagnostic tests for lead in the blood. Br J Oral Maxillofac Surg 2017;55:105.

5. Pigatto PD, Ronchi A, Guzzi G. Iron overload, G6PD deficiency, and lead levels on blood smears. Int J Hematol 2016;103:724.
6. Casarett LJ, Doull J, Klaassen CD. Casarett and Doull's toxicology: the basic science of poisons. 6th ed. New York: McGraw-Hill Medical Pub. Division; 2001. p. xix, 1236.

7. Fox DA, Kala SV, Hamilton WR, Johnson JE, O'Callaghan JP. Low-level human equivalent gestational lead exposure produces supernormal scotopic electroretinograms, increased retinal neurogenesis, and decreased retinal dopamine utilization in rats. Environ Health Perspect 2008;116:618-625.

8. Citirik $M$, Acaroglu $G$, Mutluay $A H$, Zilelioglu O. Lead poisoning: report of a case. Ann Ophthalmol 2004;36:3236.

9. Gilhotra JS, Von Lany H, Sharp DM. Retinal lead toxicity. Indian J Ophthalmol 2007;55:152-154.

10. Nagpal AG, Brodie SE. Supranormal electroretinogram in a 10-year-old girl with lead toxicity. Doc Ophthalmol 2009;118:163-166.

11. Sharma P, Sharma R. Toxic optic neuropathy. Indian J Ophthalmol 2011;59:137-141.

12. Grzybowski A, Zulsdorff M, Wilhelm H, Tonagel F. Toxic optic neuropathies: an updated review. Acta Ophthalmol 2015;93:402-410.

13. Saldana M, Collins CE, Gale R, Backhouse O. Diet-related mercury poisoning resulting in visual loss. $\mathrm{Br} J$ Ophthalmol 2006;90:1432-1434.

14. Pamphlett R, Kum Jew S, Cherepanoff S. Mercury in the retina and optic nerve following prenatal exposure to mercury vapor. PLoS One 2019;14:e0220859.

15. Phelps J. Headliners: lead exposure and vision. Environ Health Perspect 2005;113:A163. 